\title{
The role of crisis management in urban infrastructure development
}

\author{
Jamaleddin Honarvar ${ }^{1}$ \\ Islamic Azad University Central Tehran Branch (IAUCTB)
}

\begin{abstract}
Crisis management is a terminology in the field of management, which refers to a set of activities, alternatives, and guidelines that an organization manages to address in a crisis with the aim of reducing the trend, control and resolution of the crisis. In general, crisis management means the purposeful advance of the progress of affairs, the controllable process, and the expectation of returning affairs as soon as possible to the pre-crisis conditions. Creating, managing crisis, all actions related to prevention and risk management, organization and management of resources needed to respond to the crisis. The management of the applied scientific crisis is by systematic observation of crises and their analysis, seeking to find a means by which they can prevent crises, or if they do so, to reduce the effects of the crisis, to prepare for the necessary relief Quick and remedy. Due to the expansion of urban population and the above description of the role of crisis and crisis management and its importance, this research tries to reduce the potential risks of threats to crises in urban spaces through the creation or development of urban spaces and infrastructures.
\end{abstract}

Key word: crisis, crisis management, urban infrastructure, development 


\section{International Conference on Advanced Research in MANAGEMENT, ECONOMICS AND ACCOUNTING}

\section{5-7 September, 2019}

Barcelona, spain
$\mathrm{MEA}$

MANAGEMENT, ECONOMICS \& ACCOUNTING CONFERENCE

\section{Introduction}

The subject of the development of subterranean spaces has always been considered and used in various forms and purposes throughout history. For example, we can mention life in caves to mining, and the creation of water networks. But the peak in thinking of using these spaces as a way to solve urban problems began with the formation of the tunneling association in 1974 [5].

Obviously, the result of the overwhelming growth of the population in large cities, the vertical and horizontal development of cities, the congestion of the building and the lack of open urban spaces, the high vulnerability of some tissues Urban against natural hazards and the lack of suitable urban spaces for use in times of crisis. In such a situation, a new development is needed to solve these challenges.

Therefore, due to the potential and capacities of the above subterranean spaces, the need to exploit these spaces is becoming more and more evident.

Unfortunately, the impact of environmental hazards on developing countries is greater than in advanced countries, and as such, one of the most important issues at the 2012 World Tunnel Conference in Bangkok, Thailand, is to reduce the risks of natural disasters and manage them through Use of subsurface spaces.

Japan is one of the most advanced countries in the field, creating a crisis management system for subterranean spaces in September 2001 [15].

\section{The concept of infrastructure and its features}

Urban subterranean spaces are spaces with various structures and functions, including storage, industry, transportation, communications, public services, and private and personal uses. [4].

Understanding potential of subterranean spaces can be effective in solving the problems caused by population growth. Among these capabilities and potentials are the following:

- Locate some urban applications: Provide the possibility of locating applications and services that could be created on the ground for reasons such as lack of space or incompatibility.

- Ability to protect against adverse conditions: Infrastructures appear to be inferior to Surface structures will have less impact on earthquake waves and, consequently, less damage. Except for a number of specific degradations in the subsurface transport debate, the rest of the underlying infrastructure in recent earthquakes has proven to be good.

Subterranean spaces due to placement among soil masses relative to surface structures in contrast to the vibrations produced by the explosion and the resulting shock, they exhibit greater resistance. On the other hand, these structures are resistant to leakage of radioactive materials, as many of these hazardous materials are absorbed by a few inches of concrete, steel, and soil. Underground structures, especially if they have the ability to dispose of or filter out 


\section{International Conference on Advanced Research in MANAGEMENT, ECONOMICS AND ACCOUNTING}

\section{5-7 September, 2019}

MEA

MANAGEMENT, ECONOMICS \& ACCOUNTING CONFERENCE

external contaminated air, are very valuable shelters in emergencies [13]. In general, due to its non-flammable properties, the earth is a very good insulator for its underlying structures, and the surface of the earth is potentially protected from external fires.

- Economic savings: Physical benefits of underground buildings can have direct costs in reducing costs compared to overhead facilities. For example, insulation against heat changes reduces the demand for embedded air conditioning systems.

- Increasing the efficiency of the transportation system: The use of safety and speed sub-surface transport systems for users, and in case of emergencies and obstruction of surface roads, due to the deposition of rubble, is a very reliable alternative for the rapid transfer of injured persons and operations Relief is considered.

- Environmental protection: Important issues such as climate pollution, lack of open and green spaces and the burying of hazardous materials are among the environmental problems that can be greatly reduced by the use of subterranean spaces.

- The possibility of generating energy transfers tones: Infrastructures are elements that are tied to the physical life of the community and are, in contrast to the superstructure of equipment and facilities for the survival and safety of urban life.

\section{The concept of crisis management and its various stages}

Several definitions have been proposed for crisis management, among them One can refer to the definition of the American Management Association 3 per year 2003 has provided. "managing a crisis is a process for which Preventing a crisis or minimizing its effects when it occurs Takes place. To do this, the process has to deal with the worst the situation is also planned and then the methods for manage and do it" [2]. Identification of risks in Architecture and Urbanism projects is based primarily on determining what types of risks may affect the project, identifying their characteristic parameters and estimating the probability of their occurrence in the project. The need for risk identification stems from the decision-making conditions under which an investor is at the moment [3].

Crisis management involves the following steps:

- Understanding the problems through available information and news about the crisis.

- Describing and formulating possible options to control and harness crisis.

- Lowering the various costs to just one option and choosing the best strategy.

- Assessing negative and positive feedback about each strategy

- Understanding the vulnerabilities and threats

- Analyzing risks.

- Responding Crisis. 


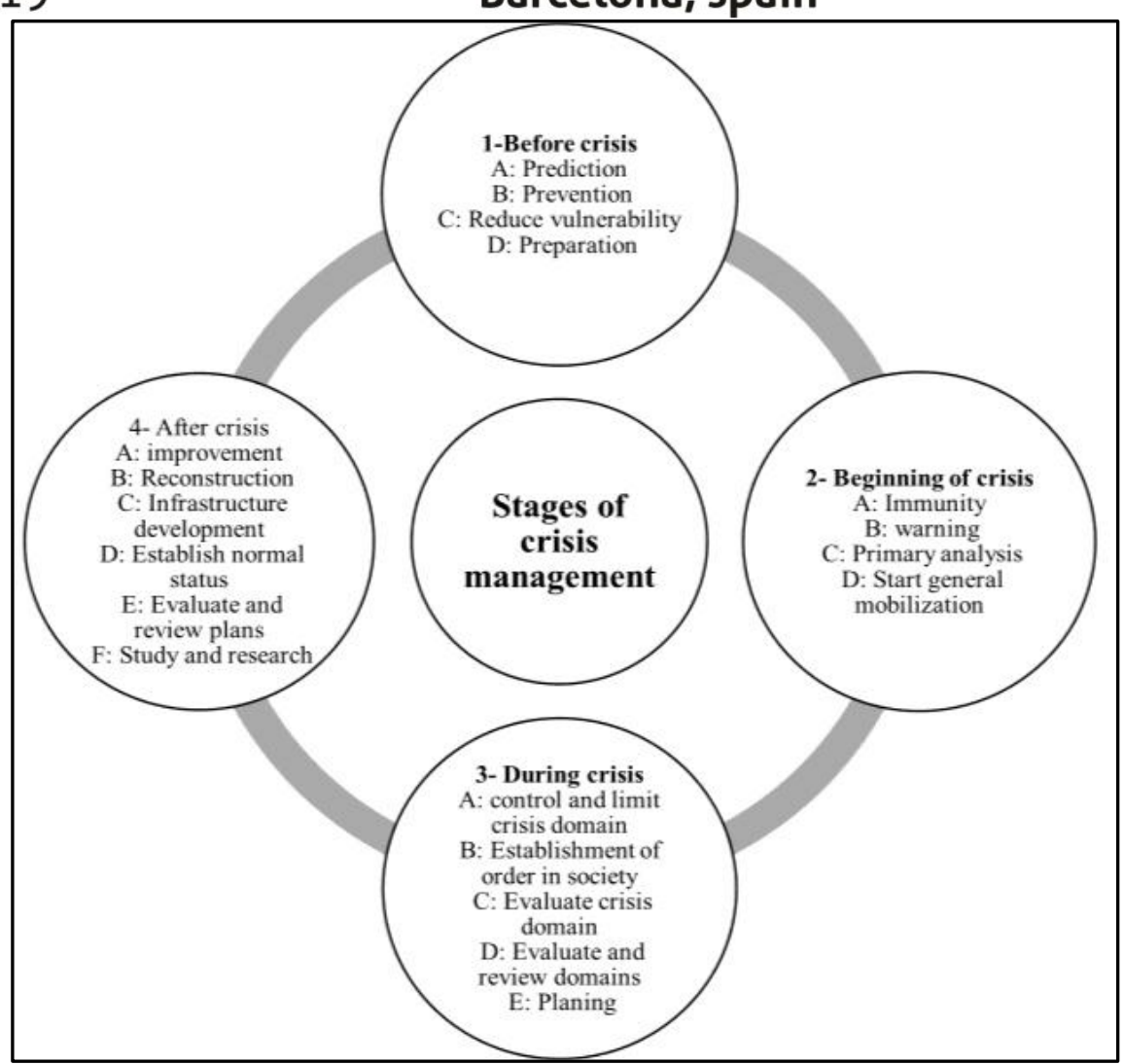

Figure 1. The main cycle of crisis management [14].

\section{Urban Management and Crisis Management}

Cities are important centers of modern societies that will continue to gain in importance in the future. Today, more than half the world's population lives in urban areas. Not only people (residents, commuters, and tourists) are concentrated in cities, but also infrastructures, whose importance extends far beyond municipal, and often national borders. These include transport, communication, and energy networks, as well as educational and healthcare facilities. More than 80 per cent of global economic output is generated in cities [11]. 


\section{International Conference on Advanced Research in MANAGEMENT, ECONOMICS AND ACCOUNTING}

\section{5-7 September, 2019}

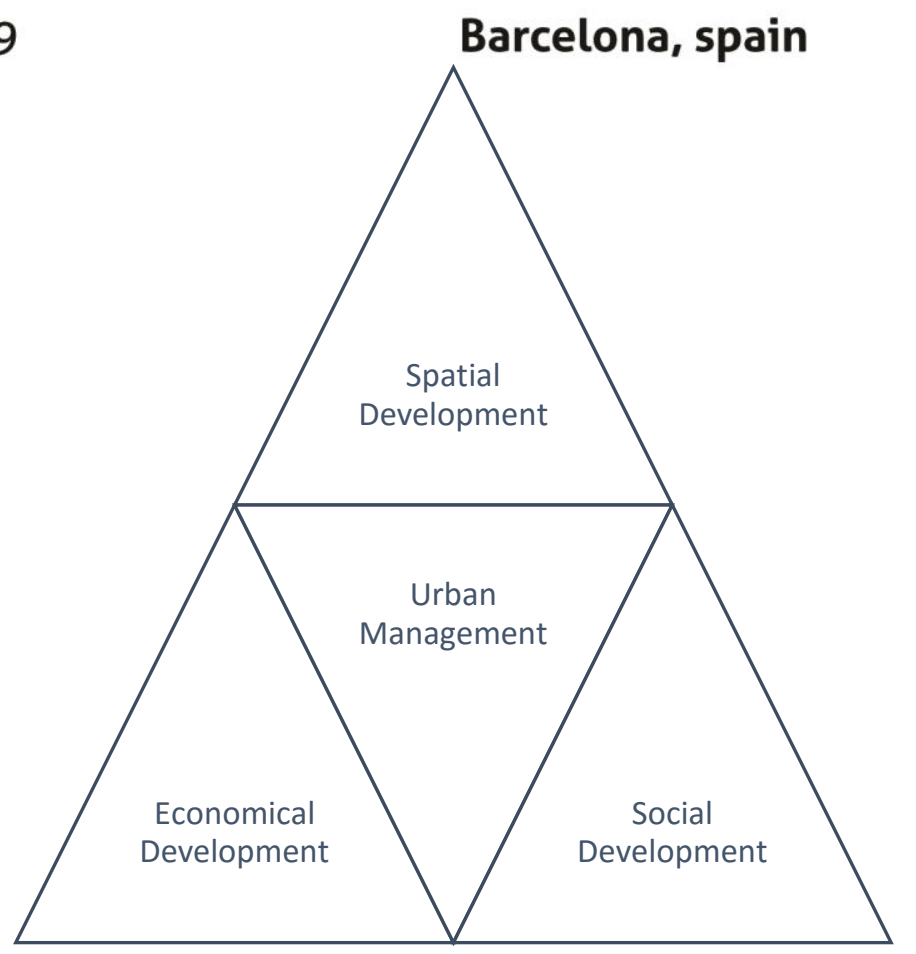

Figure 2. The Pyramid of Urban management, source: author.
$\mathrm{M}_{\mathrm{E}} \mathrm{A}$

MANAGEMENT, ECONOMICS \& ACCOUNTING CONFERENCE

Way of responding to natural disasters and solving the crisis which caused by events have a direct relation with level of development and achievements of each country. It means that more investment on developing and improving infrastructures of country in order to reduce casualties will have faced negative effects of events and crisis with significant reduction [10].

The role of urban management in helping large community management can be summarized as follows:

The city administration and any other management are trying to reduce the crisis, which, of course, is intelligent Problems cannot be solved at all. Basically, a crisis arises when management over the course of time has not seen or solved small issues or attempts to change the issues, which has led to acute issues ultimately turning into a mass of problems and problems that are hardly solvable. Being called into crisis.

City management can be based on your own knowledge and information about your city avoid widespread crises. For example, consider a metropolis that it is located on an earthquake and has a gas network. If in the event of an earthquake, proper systems are not considered to reduce its effects, or if there is no thought to stop the gas at the time of the earthquake, it will not only earthquake in the city, but the city will burn in the fire. Of course, a peripheral environmental solution may require more action, but a solution to the crisis Socioeconomic requires more effort and co-operation and coordination between the existing institutions has a city. Because urban management has duties and this task is with the responsibilities of other management so, before the crisis or during and after the crisis, this relationship overlaps in the city. Effective 


\section{International Conference on Advanced Research in MANAGEMENT, ECONOMICS AND ACCOUNTING}

\section{5-7 September, 2019}

Barcelona, spain

MEA

MANAGEMENT, ECONOMICS \& ACCOUNTING CONFERENCE

and positive role should be placed between managers. Of course, the urban manager is responsible for the key issues during the crisis and after a major crisis.

It is possible that the crises did not originate in the first place due to the management of the city Continued and even more extensive can be due to lack of proper urban management Whether this margin would turn into a threat (or threat) or a suburb (opportunity) This is due to CMS and urban management plans.

In the case of cultural affairs, it can also be said that urban management is directly "responsible for comprehensive culture It does not deal with such a massive people, but it may be due to inappropriate urban management with the issues Do not. This can cause problems. The process of urban planning includes three main steps: Recognition of the present status of the situation, analysis and final planning [12]. It was awesome and etc. Instead, it should look at the urban issues with a systemic view. It has happened many times Decisions have been made in the city that not only did not resolve any problems, but it also provoked itself There are other problems.

Table 1. Criteria of underground space development. Source: Author

\begin{tabular}{|c|c|}
\hline Levels & Criterion \\
\hline $\begin{array}{c}\text { Prevention and } \\
\text { preparedness }\end{array}$ & $\begin{array}{l}\text { - } \text { reduction in costs } \\
\text { - Manage land use } \\
\text { and identify } \\
\text { hotspots } \\
\text { - Urban facilities } \\
\text { and infrastructure } \\
\text { - City } \\
\text { communication } \\
\text { network } \\
\text { - Attention to human } \\
\text { needs }\end{array}$ \\
\hline Confronting & $\begin{array}{ll}\text { - } & \text { Relief } \\
\text { - } & \text { Improved } \\
& \text { transportation } \\
& \text { networks } \\
\text { - } & \text { Collective } \\
& \text { activities }\end{array}$ \\
\hline Reconstruction & $\begin{array}{l}\text { - Improve the spatial } \\
\text { structure of the } \\
\text { city }\end{array}$ \\
\hline
\end{tabular}




\begin{tabular}{|l|l|}
\hline & $\bullet \begin{array}{l}\text { Establishing } \\
\text { security and peace } \\
\text { • }\end{array}$ \\
& $\begin{array}{l}\text { Preventing damage } \\
\text { to the urban } \\
\text { environment }\end{array}$ \\
\hline
\end{tabular}

\section{Criteria for using infrastructures during the crisis}

At this stage, following the occurrence of the crisis, the operation of relief operations, the accommodation of people in safe areas of dismantling, and the improvement of roads and ... begins. Effective measures at this stage are very important in reducing harm. The effective measures in subsurface development during the crisis are:

- Improved access paths: through the depletion of passages and access points to subsurface areas.

- Readability: Through the use of an emergency power system in the event of power outage, the use of clear signs and indications in the direction of relief routes.

- Relief: through the use of emergency motorways below the surface for the rapid transfer of the wounded, the transfer of persons to safe havens and shelters and etc.

- Establishing social justice: creating a sense of equality and friendship during relief operations and paying special attention to vulnerable groups ....

\section{Criteria for the use of infrastructures in the post-crisis phase}

It is important to continue the process of actions taken during the crisis, to restore society to normal, to rebuild and repair damaged structures, to provide acceptable living conditions in the temporary accommodation of the people, and to provide financial and mental security to the people of the community.

Therefore, the most important criteria for the development of subsurface spaces at this stage are:

- Maintenance: continuous maintenance of subsurface facilities, repair of subsurface emergency roads, care and improvement of information systems.

- Preventing damage to the urban environment: Using the underlying layers of the earth to transport waste and hazardous waste, and prevent the transfer and leakage of toxic substances to superficial spaces. 


\section{International Conference on Advanced Research in MANAGEMENT, ECONOMICS AND ACCOUNTING}

\section{5-7 September, 2019}

Barcelona, spain

MEA

MANAGEMENT, ECONOMICS \& ACCOUNTING CONFERENCE

- Liveliness: Creates vitality in subsurface areas through the possibility of multipurpose use of space designed for crisis management.

\section{Conclusion}

Various studies, both scientific-research as well as derived strictly from everyday life have shown that risk is a measurable entity and therefore predictable. Modern science provides us with many tools and methods to identify and measure risk such as newer and more perfect programs and systems to calculate the scale and magnitude of risk occurrence. Also our knowledge on this subject changed over the last few years. Construction companies and investors started to appreciate the tools in the form of schedules or computer analysis for effective investment planning. It was realized that a correctly executed project plan and risk identified at the outset may at a later stage turn into success for the project. Such measures have become necessary taking into account at least the delays in the implementation of many key investments. As a result of this study, proper management of the crisis could contribute to the development of urban infrastructure, otherwise we face unrecoverable injuries in urban environments.

\section{Reference}

[1] Alexander D. 2002. Principles of Emergency and Managements. Oxford University Press. p 38.

[2] American Management Association. (2003). Crisis management and security issues.

[3] Bizon-Górecka J., Zastosowanie innowacyjne na przykładzie branży budowlanej, materiały konferencyjne Technologia i zarządzanie w budownictwie, Wrocław 2006, s. 175-182, Prace Naukowe Instytutu Budownictwa Politechniki Wrocławskiej nr 87.

[4] Bobylev, N. (2009). Urban Underground Infrastructure and Climate Change Opportunities and Threats. Fifth Urban Research Symposium. Marseille, France June 2830, 2009.

[5] Broere, W. (2013). Urban Problems Underground Solution. Advances in Underground Space Development. Singapore: Research Publishing.

[6] Carmona, M, 2007, Heat, T, Oc, T, Ties dell, S. Public Places-Urban Spaces, Architectural Press, London.

[7] Chong Y.Y., Brown E.M., Zarządzanie ryzykiem projektu, Oficyna Ekonomiczna, Kraków 2001

[8] Dokumenty formalne, przygotowane na potrzeby realizacji Kontrakt nr 5/FS2 Aglomeracja Kórnik: Rozbudowa i modernizacja oczyszczalni ścieków w Borówcu, autorstwa "ECM GROUP POLSKA" SP. Z O.O., 2010

[9]Hosseini,R. Establishing Indices of Underground Space Development In Terms of Urban Crisis Management Criteria. Vol.12, No.35, The Scientific Journal (NRC), 2015. [10] Lewis J. 1981. Mitigation Preparedness Measures. In Disaster and the Small Dwelling. ed. -Lan Davis. Pergamon press. Oxford. Michigan University. p 33 


\section{International Conference on Advanced Research in MANAGEMENT, ECONOMICS AND ACCOUNTING}

5-7 September, 2019

Barcelona, spain

$\mathrm{M}_{\mathrm{E} A}$

MANAGEMENT, ECONOMICS \& ACCOUNTING CONFERENCE

[11] Maduz, 1. Roth, F. The Urbanization of Disaster Management, Editor: M. Bieri. CSS Analysis in Security Policy, No. 204, March 2017.

[12] Shiee E, 2006. Principles of Urban Planning. Tehran: Iran University of Science and Technology Press.

[13] Stirling, R. \& carmody, J. (2010). Design of underground spaces, Guide of operation of Underground Space and People oriented planning and design in these spaces.

[14] Teymoori M. 2004. Crisis management in Historical textures. Attachment of Municipalities monthly. No.16. p 22

[15] www.tunnel-online.info/en 